\title{
CANINE VISCERAL LEISHMANIASIS DUE TO Leishmania (L.) infantum chagasi IN AMAZONIAN BRAZIL: COMPARISON OF THE PARASITE DENSITY FROM THE SKIN, LYMPH NODE AND VISCERAL TISSUES BETWEEN SYMPTOMATIC AND ASYMPTOMATIC, SEROPOSITIVE DOGS
}

\begin{abstract}
SUMMARY
Canine visceral leishmaniasis (CVL) is recognizable by characteristic signs of disease and is highly lethal. The infection, however, may be quite inapparent in some seropositive dogs, and this has raised the polemic question as to whether or not such animals can be a source of infection for Lutzomyia longipalpis, the vector of American visceral leishmaniasis (AVL). In this study we have examined 51 dogs with acute CVL from an AVL area in Pará State, northern Brazil, and compared the parasite density, amastigotes of Leishmania (L.) infantum chagasi, in the skin, lymph node and viscera of symptomatic with that of nine asymptomatic but seropositive dogs (IFAT$\mathrm{IgG})$. Post-mortem biopsy fragments of these tissues were processed by immunohistochemistry, using a polyclonal antibody against Leishmania sp. The $\mathrm{X}^{2}$ and Mann Whitney tests were used to evaluate the means of infected macrophage density $(p<0.05)$. There was no difference $(p>0.05)$ in the skin $\left(10.7 / \mathrm{mm}^{2} \times 15.5 / \mathrm{mm}^{2}\right)$ and lymph node $\left(6.3 / \mathrm{mm}^{2} \times 8.3 / \mathrm{mm}^{2}\right)$, between asymptomatic and symptomatic dogs, respectively. It was higher $(p<0.05)$, however, in the viscera of symptomatic $\left(5.3 / \mathrm{mm}^{2}\right)$ than it was in asymptomatic $\left(1.4 / \mathrm{mm}^{2}\right)$ dogs. These results strongly suggest that asymptomatic or symptomatic $L$. $(L$. $)$ i. chagasi-infected dogs can serve as a source of infection, principally considering the highest $(p<0.05)$ parasite density from skin $\left(10.7 / \mathrm{mm}^{2} \times 15.5 / \mathrm{mm}^{2}\right)$, the place where the vetor L. longipalpis takes its blood meal, compared with those from lymph node $\left(6.3 / \mathrm{mm}^{2} \times 8.3 / \mathrm{mm}^{2}\right)$ and viscera $\left(1.4 / \mathrm{mm}^{2} \times 5.3 / \mathrm{mm}^{2}\right)$.
\end{abstract}

KEYWORDS: Canine visceral leishmaniasis; Leishmania (L.) infantum chagasi; Symptomatic and asymptomatic dogs; Parasite density; Amazonian Brazil.

\section{INTRODUCTION}

In Amazonian Brazil, American visceral leishmaniasis (AVL) is an anthropozoonotic disease, strongly associated with an enzootic cycle of Leishmania (Leishmania) infantum chagasi (= Leishmania chagasi Cunha and Chagas 1937) in the fox Cerdocyon thous ${ }^{17,18,31}$. Transmission of the parasite in these animals of northern Brazil is considered to be maintained by the phlebotomine sandfly vector Lutzomyia longipalpis ${ }^{19,32}$. This silvatic enzootic, it has been suggested, was probably the origin of the major foci of human AVL in this region ${ }^{14}$, principally in the State of Pará where the ecology and epidemiology of the disease has been studied during the last sixty years ${ }^{5,15}$.

Progressive increase in the number of human AVL cases in Pará State during recent years ${ }^{30}$ has been facilitated by the steadily increasing population of the highly susceptible domestic dog, Canis familiaris, which has now become the major peridomestic source of human infection ${ }^{15,16}$. As a result, the culling of clinically symptomatic and asymptomatic but seropositive dogs has been regarded as a major control measure against the human disease ${ }^{4}$.

There is, nevertheless, a growing opinion that this control measure, particularly the destruction of the asymptomatic, serologically positive dogs, has failed to result in any lasting decrease in the incidence of human and/or canine AVL in Brazil ${ }^{1,10}$, thus placing the Brazilian health authorities in a somewhat delicate situation.

With this in mind, the following study has compared the parasite density (amastigotes) of the acutely infected, sick dog with that of the asymptomatic but seropositive animal, in an attempt to indicate the degree with which the latter may serve as a source of infection for the sandfly vector.

\section{MATERIAL AND METHODS}

Dogs: Sixty mongrel dogs were randomly examined, thirty-four

(1) Departamento de Parasitologia, Instituto Evandro Chagas (Secretaria de Vigilância em Saúde, Ministério da Saúde), Rd. BR 316 (S/N), $67030-000$ Ananindeua, Pará, Brasil.

(2) Departamento de Saúde Pública, Secretaria de Saúde do Município de Barcarena, Pará, Brasil.

(3) Departamento de Patologia, Faculdade de Medicina, Universidade de São Paulo (USP), São Paulo, SP, Brasil.

(4) Núcleo de Medicina Tropical, Universidade Federal do Pará (UFPa), Belém, Pará, Brasil.

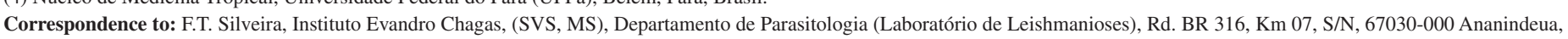
Pará, Brasil. Phone/Fax: +55 91 3214-2043. E-mail: fernandotobias@iec.pa.gov.br 


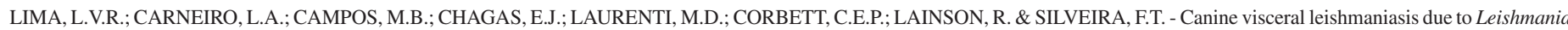
(L.) infantum chagasi in Amazonian Brazil: comparison of the parasite density from the skin, lymph node and visceral tissues between symptomatic and asymptomatic, seropositive dogs. Rev. Inst. Med. Trop. Sao Paulo, 52(5): 259-65, 2010.

(57\%) males and twenty-six (43\%) females. They ranged from one to seven years old and were from the Santana do Cafezal village, an area of AVL situated on the banks of the river Cafezal, $7 \mathrm{~km}$ from the administrative centre of Barcarena municipality ( $01^{\circ} 30^{\prime} \mathrm{S}$ : $\left.48^{\circ} 37^{\prime} \mathrm{W}\right)$, which is considered to be within the metropolitan region of Belém, Pará State, north of Brazil ${ }^{33}$. All dogs had given seropositive results in the indirect fluorescent antibody test (IFAT-IgG) for visceral leishmaniasis, using a highly species-specific $L$. (L.) $i$. chagasi-amastigote antigen from a strain of the parasite (MCAO/BR/2003/M22697 - Barcarena, Pará) isolated from a dog in the same locality ${ }^{25}$. This antigen has proved to be more specific than the commercially available IFAT or ELISA kits (Bio-Manguinhos, Rio de Janeiro, Brazil) ${ }^{9}$. The seropositive dogs were euthanized, as recommended by the Brazilian control program of $\mathrm{AVL}^{4}$.

Clinical evaluation: This was based on the classical clinical signs described for canine leishmaniasis, principally lymphadenopathy, splenomegaly, hepatomegaly, weight loss, alopecia and onychogryphosis ${ }^{11,12}$. Dogs with one or more clinical signs were regarded as symptomatic (51-85\%) and those with no clinical sign as asymptomatic (9-15\%).

Proceedings for collection of tissue samples: Before euthanasia, the dogs were anesthetized with sodium thiopental $25 \mathrm{mg} / \mathrm{kg}$; following that, euthanasia was performed by intravenous injection of $19.1 \%$ potassium chloride, and post-mortem biopsies were made from the skin from the upper triangle of the ear (frequently compromised in symptomatic dogs), popliteal lymph node and viscera (liver and spleen) from all sixty seropositive dogs. The tissues were fixed in neutral formalin solution $(10 \%, \mathrm{pH} 7.2)$ and embedded in paraffin wax for the preparation of histological sections, cut at approximately $4.0 \mu \mathrm{m}$. Besides these, blood samples were drawn by jugular puncture and serum samples of all dogs were stored at $-20{ }^{\circ} \mathrm{C}$ for evaluating the final titer of the IFAT (IgG) reaction for each dog.

Evaluation of the parasite density: The genus Leishmania is an obligate intracellular parasite of the mononuclear cells (principally the macrophage) and the parasite density was, therefore, estimated by determining the infected macrophage density in the above-mentioned tissues from all of the seropositive dogs examined. This was obtained by the use of an immunohistochemical study of histological sections using a polyclonal antibody for the recognition of $L$. (L.) $i$. chagasi-amastigotes in parasitized macrophages ${ }^{24}$, as well as for the cellular analysis of immuno-labeled macrophage density ${ }^{6}$.

Immunohistochemistry procedure: This followed the procedure described by MOREIRA et $a l .{ }^{24}$. The paraffin-wax embedded sections were de-waxed and rehydrated, and the antigen retrieved by steaming in $10 \mathrm{mM}$ citric acid solution $(\mathrm{pH}$ 6.0) for three minutes in a pressure cooker. Endogenous peroxidase activity was blocked with $3 \%$ hydrogen peroxide and nonspecific interactions with a solution of powdered skimmed milk, $60 \mathrm{~g} / \mathrm{L}$ in distilled water. Immuno-labeling was performed with mouse anti-Leishmania polyclonal antibody diluted $1 / 800$ in $0.01 \mathrm{M}$ PBS containing $1 \%$ bovine serum albumin: incubation was carried out in a humid chamber, at $4{ }^{\circ} \mathrm{C}$, overnight. After washing, the sections were incubated with a biotinylated secondary antibody, and then with a streptavidin-peroxidase complex from LSAB kit (Dako, USA): both incubations were performed at $37{ }^{\circ} \mathrm{C}$ for 30 minutes. Colour reaction was developed for five minutes at room temperature using, as substrate, 3-3-diamenobenzidine (Sigma, USA) at $60 \mathrm{mg} / 100 \mathrm{~mL}$ of $0.01 \mathrm{M}$ PBS containing $1 \%$ hydrogen peroxide. The sections were counterstained with haematoxylin, dehydrated and mounted in resin.

Cellular density of infected macrophage: An image analysis system was used to evaluate the infected macrophage density in the sections of each tissue, which enabled a count of the macrophages containing immunolabeled amastigotes. A colour video camera and monitor-connected "AxionVision" microscope (Zeiss) were used, and the infected cells counted in 5-10 microscopic fields of each tissue using the $\mathrm{x} 40$ objective and $\mathrm{x} 10$ eyepieces. A brown rim over the cytoplasmic membrane of the amastigotes was taken to indicate positively-stained cells.

Comparison of the parasite density: The comparison of the parasite density in the symptomatic and asymptomatic dogs was based on the means of the infected macrophage density for each tissue examined, i.e., the skin, lymph node and viscera (liver plus spleen): the total parasite density $(T p d)$ being the sum of that recorded for each tissue.

Evaluation of the total parasite density (Tpd) correlated with the antibody response: Dogs were divided into two groups: a) those with a low IFAT-IgG titre (80-640) [n = 31] and, b) those with a high titre $(\geq 1280)$ [ $\mathrm{n}=29$ ]. The Tpd of the two groups was then compared.

Parasitological evaluation by Giemsa-staining method: The traditional Giemsa-staining method was also used for a parasitological evaluation of sections of tissues from ten randomly selected seropositive dogs with the aim of a comparison with the immunohistochemical method.

Data analysis: Data obtained were analyzed by the Bio-Estat 4.0 software ${ }^{2}: X^{2}$ was used to evaluate the infection prevalence, and the Mann Whitney test to compare parasite density, with $p$ values $<0.05$ for both of these and the descriptive statistics for demonstrating the means of infected macrophage densities of comparable variables.

Ethical approval: This study was approved by the Ethics Committee in Animal Research of the Instituto Evandro Chagas (IEC), Surveillance Secretary of Health, Ministry of Health, Brazil, with the protocol number 018/2005/CEPAN/IEC/SVS/MS/Brasil.

\section{RESULTS}

To obtain a better understanding regarding the diagnostic approach in canine $L$. (L.) $i$. chagasi infection, the results obtained were divided into five sections, as follows:

Evaluation of immunohistochemistry as a diagnostic tool: To indicate the value of immunohistochemistry as a well-defined method for the diagnosis of canine $L$. (L.) $i$. chagasi infection, the results of its use were compared with the traditional Giemsa-staining method in the examination of sections of tissues from ten randomly selected seropositive dogs. The results showed $100 \%$ immunohistochemistry reactivity in the skin, lymph node and viscera, whereas Giemsa reactivity was $80 \%(8 / 10)$ in the skin and $70 \%(7 / 10)$ in the lymph node and visceral tissues. These results indicated that the immunohistochemistry method gave at least a somewhat better performance as a diagnostic tool for the diagnostic of canine $L$. $(L$. $)$ $i$. chagasi infection, in histological sections, than did Giemsa-staining. 


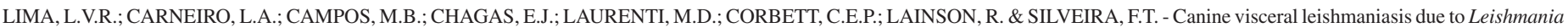
(L.) infantum chagasi in Amazonian Brazil: comparison of the parasite density from the skin, lymph node and visceral tissues between symptomatic and asymptomatic, seropositive dogs. Rev. Inst. Med. Trop. Sao Paulo, 52(5): 259-65, 2010.

Distribution of infection in the tissues of dogs related to clinical state: Lymph node was the most commonly infected tissue (100\%), in both the symptomatic (51) and asymptomatic (nine) dogs. The viscera were $100 \%$ parasitized in the symptomatic animals and $98 \%$ in the asymptomatic. The skin was the least commonly parasitized tissue, $81.2 \%$ in the symptomatic dogs and $55.5 \%$ in the asymptomatic.

Comparison of the parasite density (infected macrophage density) in the skin, lymph node and viscera (liver plus spleen) between asymptomatic and symptomatic, seropositive dogs: This diagnostic approach allowed the use of two types of analysis: in the first analysis there was no significant difference $(p>0.05)$ in the parasite density of the skin $\left(10.7 / \mathrm{mm}^{2} v 15.5 / \mathrm{mm}^{2}\right)$ and lymph node $\left(6.3 / \mathrm{mm}^{2} v 8.3 / \mathrm{mm}^{2}\right)$, between the asymptomatic and symptomatic dogs, respectively. In the viscera, however, a difference $(p<0.05)$ existed $\left(1.4 / \mathrm{mm}^{2} v 5.3 / \mathrm{mm}^{2}\right)$ between these two groups of dogs (Fig. 1A, 1B and 1C). In the second analysis, the parasite density of different tissues was compared amongst dogs within the same clinical category: this indicated that the parasite density in the skin of asymptomatic dogs $\left(10.7 / \mathrm{mm}^{2}\right)$ was higher $(p<$ $0.05)$ than that in the lymph node $\left(6.3 / \mathrm{mm}^{2}\right)$ and viscera $\left(1.4 / \mathrm{mm}^{2}\right)$. In addition, the parasite density in the skin of symptomatic dogs (15.5/ $\left.\mathrm{mm}^{2}\right)$ was also higher $(p<0.05)$ than that in lymph node $\left(8.3 / \mathrm{mm}^{2}\right)$ and viscera $\left(5.3 / \mathrm{mm}^{2}\right)$ (Fig. $2 \mathrm{~A}$ and $\left.2 \mathrm{~B}\right)$.

Comparison of the total parasite density (Tpd) between the asymptomatic and symptomatic, seropositive dogs: In order to complete our comparative analysis between asymptomatic and symptomatic dogs, it was shown that the $T p d$ of symptomatic $\operatorname{dogs}\left(8.5 / \mathrm{mm}^{2}\right)$ was higher $(p$ $<0.05)$ than that of asymptomatic ones $\left(4.3 / \mathrm{mm}^{2}\right)$ (Fig. 3).

Evaluation of the total parasite density $(T p d)$ related to the antibody response: This evaluation showed a clear association between the Tpd and the humoral response (IFAT-IgG) of infected dogs: namely, those dogs with low (80-640) serological titers presented a $\operatorname{Tpd}\left(8.9 / \mathrm{mm}^{2}\right)$ which was lower $(p<0.05)$ than the $T p d\left(17.1 / \mathrm{mm}^{2}\right)$ of dogs with a high $(\geq 1280$ ) serological titre (Fig. 4).

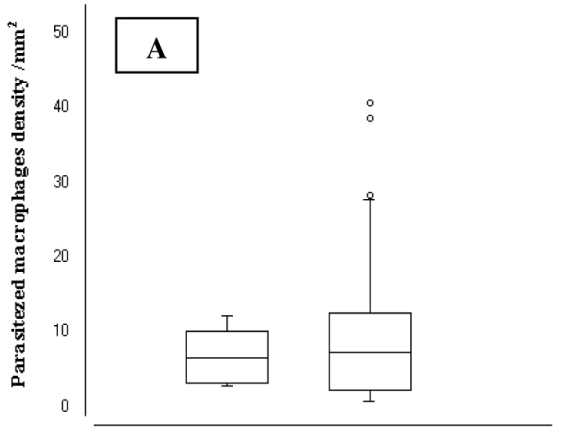

AD
SD

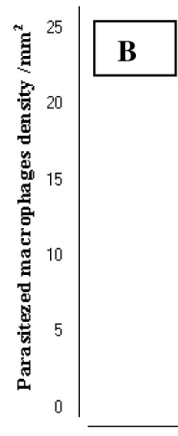

AD

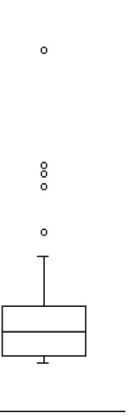

SD

$$
p=0.6176 \quad p=0.7017
$$

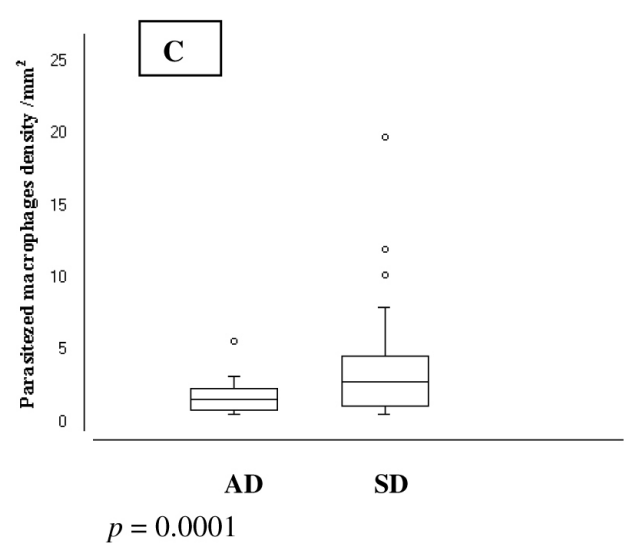

$\mathrm{AD}=$ asymptomatic dogs $; \mathrm{SD}=$ symptomatic dogs.

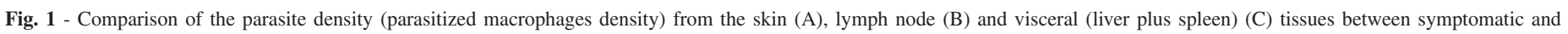
asymptomatic dogs, Santana do Cafezal village, municipality of Barcarena, Pará State, Brazil.

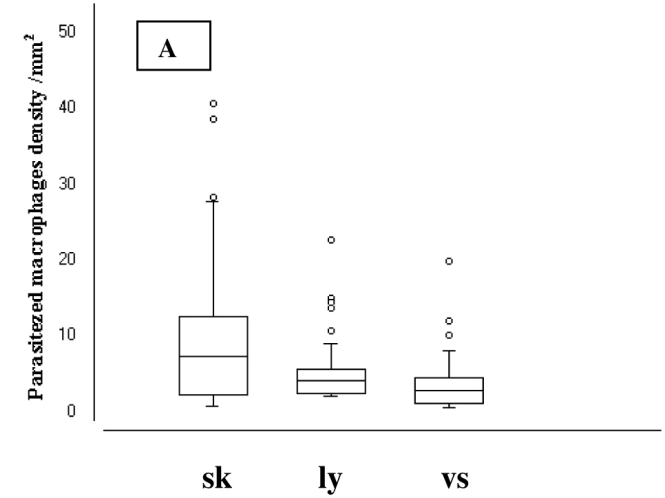

$\mathrm{sk}=\mathrm{skin} ; \mathrm{ly}=1 \mathrm{ymph}$ node; $\mathrm{vs}=$ visceral tissue;

$p=0.0021$ (sk vs ly); $p=0.0001(\mathrm{sk} v s \mathrm{vs}) ; p=0.0001$ (ly vs vs)

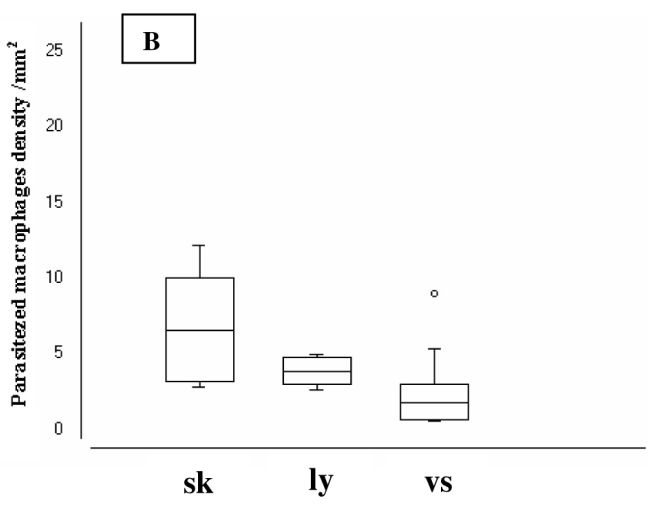

sk = skin; ly = lymph node; vs = visceral tissue $p=0.0455$ (sk vs ly); $p=0.001$ (sk vs vs); $p=0.0001$ (ly vs vs)

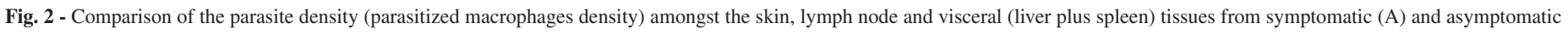
(B) dogs, Santana do Cafezal village, Barcarena municipality, Pará State, Brazil. 


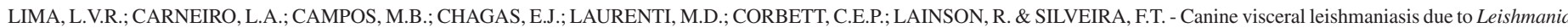
(L.) infantum chagasi in Amazonian Brazil: comparison of the parasite density from the skin, lymph node and visceral tissues between symptomatic and asymptomatic, seropositive dogs. Rev. Inst. Med. Trop. Sao Paulo, 52(5): 259-65, 2010.

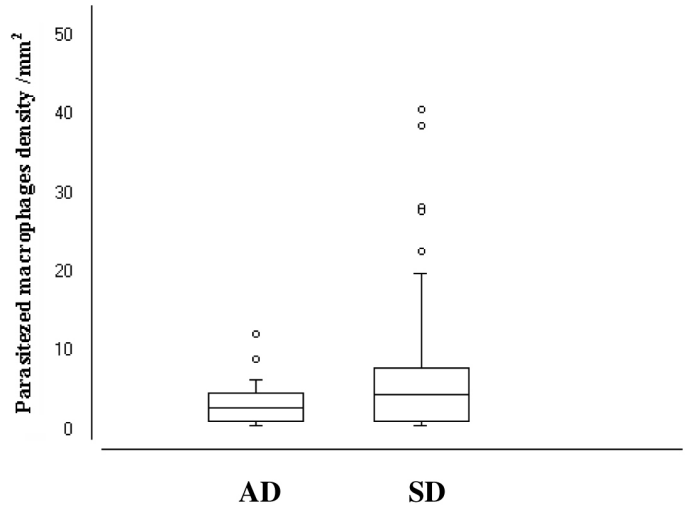

$\mathrm{AD}=$ asymptomatic dogs; $\mathrm{SD}=$ symptomatic dogs; $p=0.0003$.

Fig. 3 - Comparison of the total parasite density (parasitized macrophages density) between symptomatic and asymptomatic dogs, Santana do Cafezal village, municipality of Barcarena, Pará State, Brazil.

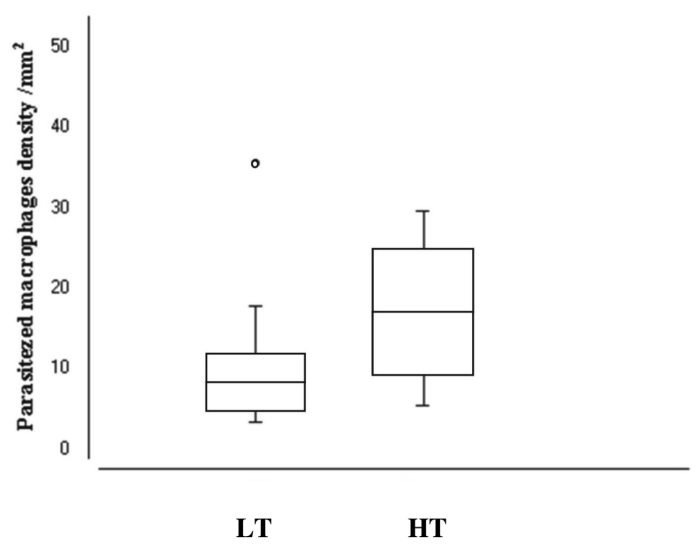

$\mathrm{LT}=$ low titer $(80-640 \mathrm{IgG}) ; \mathrm{HT}=$ high titer $(\geq 1280 \mathrm{IgG}) ; p=0.0006$.

Fig. 4 - Evaluation of the total parasite density $(T p d)$ correlated with the antibody response of seropositive dogs (IFAT-IgG) from the Santana do Cafezal village, municipality of Barcarena, Pará State, Brazil.

\section{DISCUSSION}

Firstly, it should be emphasized that the major objective of this work was to obtain information about one of the most polemic subjects regarding the epidemiology of human AVL - the role of asymptomatic dogs as a source of infection for the sandfly vector, L. longipalpis. We must also stress that this poses a rather difficult problem for the governmental programme on the control of $\mathrm{AVL}^{4}$, for although the culling of asymptomatic, seropositive dogs have been one of the principal activities in this endeavour, epidemiological studies have failed to show a lasting reduction of the incidence of human and/or canine AVL in Brazil $^{1,10}$. Also of concern is the low efficacy of amastigote detection, principally following the traditional use of Giemsa-stained smears or histological sections from the skin of dogs. Although intraperitoneal inoculation of triturated tissues into culture medium and laboratory animals such as the hamster may detect infections that have been missed by direct microscopy, cultures may be lost due to bacterial or fungal contamination and several months may be needed before infection can be detected in the hamster. Among the modern molecular biology techniques, the PCR is highly sensitive, but its high cost limits its use to well equipped reference laboratories.

We have shown that immunohistochemistry, such as that used in the present study, can provide a definite diagnosis, using a simple stained histological section of dog tissues and the common optical microscope. By this method parasites were readily detected in sections of tissues from 10 randomly selected seropositive dogs, whereas in Giemsa-stained sections it was possible to detect the parasites in only $70-80 \%$ of these animals. Using the same immunohistochemical staining, TAFURI et al. ${ }^{34}$ detected small numbers of amastigotes in the tissue of dogs with CVL in Minas Gerais State, south-eastern Brazil, and the same method has been used to detect other parasites such as Trypanosoma cruzi $^{6,26}$, Toxoplasma gondii ${ }^{7,22}$ and Leishmania (L.) donovani ${ }^{27}$.

In our study, it was of particular interest that $100 \%$ of the lymph node biopsies contained abundant amastigotes; and that although the viscera of symptomatic dogs contained detectable parasite in $100 \%$ of these animals, the liver and spleen tissues were also parasitized in $98 \%$ of asymptomatic dogs; and, finally, that the lowest detectable infection-rate was in the skin $(81.2 \%$ in the symptomatic animals and only $55.5 \%$ in the nine animals showing no signs of infection). These findings strongly support the suggestion of other authors that the best diagnostic method in screening dogs for evidence of visceral leishmaniasis, in both symptomatic and asymptomatic animals, is the staining of lymph node tissue by immunohistochemical staining ${ }^{13,20,29}$. SANCHEZ et al. ${ }^{28}$ studied the parasite density in Giemsa-stained smears of mesenteric lymph node and concluded that it was similar in both symptomatic and asymptomatic dogs.

In contrast to the similarity of the parasite density of both skin and popliteal lymph node in symptomatic and asymptomatic dogs, that of the viscera showed the significant difference $(p<0.05)$ of $5.3 / \mathrm{mm}^{2}$ and $1.4 / \mathrm{mm}^{2}$ respectively: in other words, symptomatic dogs had a visceral parasite density which was almost four times greater than that of the asymptomatic animals. According to SANCHEZ et al. ${ }^{28}$, who obtained similar results, this is due to a higher immunological resistance in asymptomatic dogs. At the same time, however, they failed to explain why a similar parasite density was found in the mesenteric (visceral) lymph node of both symptomatic and asymptomatic animals. To us, it would seem more reasonable to conclude that the considerable difference in the number of parasitized cells in the symptomatic and asymptomatic dogs was due to a difference in the duration of infection: namely, that it was quite likely that after a few months some of our nine asymptomatic dogs would have become symptomatic and with a higher visceral parasite density. This was borne out of a clinical follow-up of three asymptomatic, seropositive dogs in our study area, which all developed distinct signs of infection after periods of 4-6 months.

In considering a comparison of the average parasite density in the different tissues of dogs in the symptomatic and asymptomatic groups, it was surprising to find that in both groups it was higher in the skin (15.5/ $\mathrm{mm}^{2}$ and $\left.10.7 / \mathrm{mm}^{2}\right)$ than in the lymph node $\left(8.3 / \mathrm{mm}^{2}\right.$ and $\left.6.3 / \mathrm{mm}^{2}\right)$ and the viscera $\left(5.3 / \mathrm{mm}^{2}\right.$ and $\left.1.4 / \mathrm{mm}^{2}\right)$. This suggests that immunological resistance to infection with $L$. (L.) $i$. chagasi in the skin of dogs is less efficient than that in the lymph node and visceral tissues, even in asymptomatic animals. 


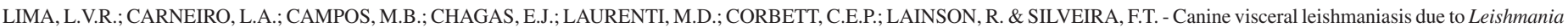

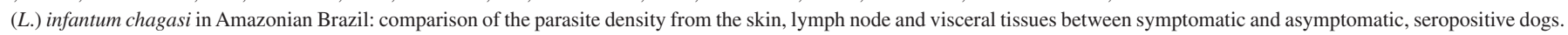
Rev. Inst. Med. Trop. Sao Paulo, 52(5): 259-65, 2010.

In our final comparative analysis, i.e. difference in the Tpd between the symptomatic and asymptomatic dogs, it was not surprising that this was higher in the former $\left(8.5 / \mathrm{mm}^{2-}\right)$ than the latter $\left(4.3 / \mathrm{mm}^{2}\right)$, although this seems not to have been previously indicated.

Regarding the possible association of the Tpd and humoral response (IFAT-IgG), our findings clearly indicated that the higher the $T p d$, the higher the humoral response will be - the tendency of infection behaviour is thus modified by the immune response of the infected host ${ }^{8}$.

Although the skin of both symptomatic and asymptomatic, seropositive dogs had the lowest infection prevalence $(81.2 \%$ and $55.5 \%$, respectively), there was no significant difference in the two groups ( $p$ $>0.05$ ). The mean parasite density for symptomatic animals was $15.5 /$ $\mathrm{mm}^{2}$ and that for the asymptomatic seropositives $10.7 / \mathrm{mm}^{2}$. This suggests that a dog of any clinical category may serve as a source of infection for the sandfly vector.

Among the asymptomatic animals there will probably be some with a high parasite density equal to that of symptomatic dogs, and it is to be admitted that we examined only nine asymptomatic animals compared with a large number (51) of dogs with clear signs of infection. The successful infection of laboratory-bred L. longipalpis fed on two of three randomly selected dogs from our asymptomatic group ${ }^{3}$, however, tends to support the conclusion that dogs with inapparent CVL are of importance in the maintenance of AVL foci ${ }^{21}$. A similar conclusion was reached regarding the transmission of the closely related Leishmania (L.) infantum infantum in the Mediterranean region of the Old World, where the vector Phlebotomus perniciosus was successfully infected when fed on asymptomatic $\operatorname{dog} s^{23}$. All these findings together suggest it best to continue the culling of all seropositive dogs in the Brazilian AVL control programme, regardless of their clinical status. In this respect it is significant that in our present study on canine AVL in the Cafezal village there was a significant reduction in the infection rate from $43.8 \%$ at initiation to only $29 \%$ one year later, after the euthanasia of the 60 seropositive $\operatorname{dog} \mathrm{s}^{25}$.

The frequently lethal outcome of American canine visceral leishmaniasis due to $L$. (L.) $i$. chagasi is in striking contrast to the consistently inapparent infection in the native fox, C. thous. Thus, none of the 14 parasitologically positive foxes found in Pará State displayed any outward signs of disease ${ }^{17,18,31}$. It is of particular interest that infection was transmitted experimentally to an uninfected fox by the bites of infected L. longipalpis, that this animal also showed no visible signs infection, and that it was possible to infect further L. longipalpis fed on it. Finally, the presence of amastigotes in the animal's skin was demonstrated by the infection of hamsters inoculated with a triturate of this tissue ${ }^{19}$.

The future control of AVL needs a network of trained personnel to make extensive and rapid collection of canine blood samples in endemic areas and promptly deposit these in laboratories for serology. Results need to be quickly made available in a central database in order to indicate the dogs that should be culled. This clearly must be accompanied by the diagnosis and treatment of human cases of AVL and attempts to eradicate the sandfly vector from its peridomestic habitat. The examination of dogs to detect enlargement of the popliteal lymph node is a useful additional diagnostic procedure, and Giemsa-stained smears of aspirated or biopsied lymph tissue will usually confirm diagnosis of infected animals.
It is to be hoped that future, improved control measures may considerably diminish the incidence of this important disease. It is unlikely, however, to eliminate it entirely in those areas where the silvatic enzootic cycle of $L$. (L.) $i$. chagasi still exists ${ }^{15,17,18}$.

\section{RESUMO}

\section{Leishmaniose visceral canina causada por Leishmania (L.) infantum chagasi na Amazônia brasileira: comparação da densidade parasitária da pele, linfonodo e vísceras entre cães soropositivos, sintomáticos e assintomáticos}

A leishmaniose visceral canina (LVC) é reconhecida pelas características clínicas da doença e é altamente letal. A infecção, entretanto, pode ser totalmente assintomática em alguns cães soropositivos, o que tem levantado questão polêmica sobre a possibilidade desses animais, serem ou não uma fonte importante da infecção para o flebotomíneo, Lutzomyia longipalpis, o principal vetor da leishmaniose visceral americana (LVA). Neste estudo foram examinados 51 cães com LVC aguda, provenientes de área endêmica de LVA no Estado do Pará, Brasil, e a carga parasitária, formas amastigotas de Leishmania (L.) infantum chagasi, na pele, linfonodo poplíteo e vísceras (fígado e baço) foi comparada com a de nove cães assintomáticos soropositivos (IFAT-IgG). Fragmentos de biópsia desses tecidos obtidos post-mortem foram processados para análise através de imunohistoquímica, usando um anticorpo policlonal contra Leishmania sp. Os testes do Qui-quadrado $\left(\mathrm{X}^{2}\right)$ e Mann Whitney foram usados para avaliar as médias da densidade de macrófagos infectados $(p<0,05)$. Os resultados mostraram que não houve diferença $(p>0,05)$ na densidade de macrófagos infectados da pele $\left(10,7 / \mathrm{mm}^{2} \times 15,5 / \mathrm{mm}^{2}\right)$ e do linfonodo $\left(6,3 / \mathrm{mm}^{2}\right.$ x $\left.8,3 / \mathrm{mm}^{2}\right)$ entre cães assintomáticos e sintomáticos. Entretanto, a densidade de macrófagos infectados da víscera de cães sintomáticos $\left(5,3 / \mathrm{mm}^{2}\right)$ foi maior $(p<0,05)$ que a de cães assintomáticos $\left(1,4 / \mathrm{mm}^{2}\right)$. Estes resultados sugerem, fortemente, que cães naturalmente infectados por $L$. (L.) i. chagasi, assintomáticos ou sintomáticos, podem servir como fonte de infecção, principalmente, considerando-se que a densidade de macrófagos infectados da pele $\left(10,7 / \mathrm{mm}^{2} \times 15,5 / \mathrm{mm}^{2}\right)$, local onde o flebotomíneo vetor $L$ u. longipalpis realiza a hematofagia, foi maior $(p<0,05)$ que as do linfonodo $\left(6,3 / \mathrm{mm}^{2} \times 8.3 / \mathrm{mm}^{2}\right)$ e vísceras $\left(1,4 / \mathrm{mm}^{2} \times 5,3 / \mathrm{mm}^{2}\right)$.

\section{ACKNOWLEDGEMENTS}

We are grateful for the technical assistance of the following people: R.N.P. Barbosa, J.A. Brandão, Z. Corrêa, E. Leão, D. Everdosa, R. de Jesus, R. Negrão, A.J. Monteiro, R. Machado, J.B. Palheta, A. Martins, J.A. Lima, I. Barata, M.S. Pinheiro, F. Medeiros, M.G.S. Silva and L.S. Eliseu.

\section{FOUNDING}

This research was supported by the Instituto Evandro Chagas (Secretaria de Vigilância em Saúde, Ministério da Saúde, Brazil); Núcleo de Medicina Tropical (Universidade Federal do Pará, Brazil); Wellcome Trust (London) and Laboratório de Investigação Médica (LIM)-50 (Hospital das Clínicas (HC)-Faculdade de Medicina (FM)-Universidade de São Paulo (USP), Brazil. 


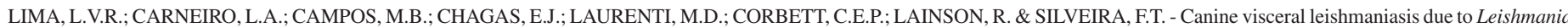
(L.) infantum chagasi in Amazonian Brazil: comparison of the parasite density from the skin, lymph node and visceral tissues between symptomatic and asymptomatic, seropositive dogs. Rev. Inst. Med. Trop. Sao Paulo, 52(5): 259-65, 2010.

\section{CONFLICTS OF INTEREST STATEMENT}

The authors have no conflicts of interest concerning this work.

\section{REFERENCES}

1. Ashford DA, David JR, Freire M, David R, Sherlock I, Eulálio MC, et al. Studies on control of visceral leishmaniasis: impact of dog control on canine and human visceral leishmaniasis in Jacobina, Bahia, Brazil. Am J Trop Med Hyg. 1998;59:53-7.

2. Ayres M, Ayres Jr M, Ayres DL, Santos AS. Bioestat 4.0: aplicações estatísticas nas áreas das Ciências Biológicas e Médicas. Belém: Sociedade Civil Mamirauá/CNPq; 2005 .

3. Barata IR, Lima JA, Soares MG, Brandão JA, Pires RN, Corrêa ZC, et al. The infectivity of dogs infected with Leishmania chagasi for Lutzomyia longipalpis is not related to clinical status or the humoral response of the animals. Abstract Book of the Third World Congress of Leishmaniasis; 2005; Palermo-Terrasini, Sicily, Italy. p. 110.

4. Brasil. Ministério da Saúde. Secretaria de Vigilância em Saúde. Departamento de Vigilância Epidemiológica. Manual de Vigilância e Controle da Leishmaniose visceral. Brasília: Ministério da Saúde; 2003.

5. Chagas E, Cunha AM, Ferreira LC, Deane L, Deane G, Guimarães FN, et al. Leishmaniose visceral americana (Relatório dos trabalhos realizados pela Comissão Encarregada do Estudo da Leishmaniose Visceral Americana em 1937). Mem Inst Oswaldo Cruz. 1938;33:89-229.

6. Corbett CEP, Ribeiro Jr U, Prianti MG, Habr-Gama A, Okumura M, Gama-Rodrigues O. Cell-mediated immune response in megacolon from patients with chronic Chagas disease. Dis Colon Rectum. 2001;44:993-8

7. Corrêa MC, Duarte MI, da Silva MA, Amato VS, Amato JG, Amato Neto V. Toxoplasmose ocular - utilização de reação imuno-histoquímica para diagnóstico. Rev Hosp Clín Fac Med São Paulo. 1996;51:141-3.

8. Cox FEG, Wakelin D. Immunology and immunopathology of human parasitic infections. In Cox FEG, Kreier JP, Wakelin D, editors. Topley \& Wilson's Microbiology and microbial infections. Volume 5: Parasitolology. $9^{\text {th }}$ ed. London: Arnold; 1998. p. 57-84

9. De Jesus RCS, Corrêa ZC, Everdosa DR, Martins AP, Eliseu LS, Campos MB, et al. Comparação das técnicas de RIFI (ag. IEC x ag. Bio-Manguinhos) e ELISA no sorodiagnóstico da leishmaniose visceral canina (LVC), Estado do Pará, Brasil. Rev Soc Bras Med Trop. 2003;36(Supl 1):323.

10. Dietze R, Barros GB, Teixeira L, Harris J, Michelson K, Falqueto A, et al. Effect of eliminating seropositive canines on the transmission of visceral leishmanisis in Brazil. Clin Infect Dis. 1997;25:1240-2.

11. Feitosa MM, Ikeda FA, Luvizotto MCR, Perri SHV. Aspectos clínicos de cães com leishmaniose visceral no município de Araçatuba, São Paulo (Brasil). Clin Vet. 2000;28:36-44

12. Ferrer L. Clinical aspects of canine leishmaniasis. In: Killick-Kendricks R, editor. Canine leishmaniasis: an update. Proceedings of the First International Canine Leishmaniasis Forum; 1999; Barcelona, Spain. p. 6-10.

13. Ferrer L, Rabanal RM, Domingo M, Ramos JA, Fondevila D. Identification of Leishmania donovani amastigotes in canine tissues by immunoperoxidase staining. Res Vet Sci. 1988;44:194-6.

14. Lainson R. Ecological interactions in the transmission of the leishmaniases. In: Anderson RM, Thresh JM, editors. The epidemiology and ecology of infectious disease agents. Cambridge: University Press; 1988.
15. Lainson R, Rangel EF. Lutzomyia longipalpis and the eco-epidemiology of American visceral leishmaniasis, with particular reference to Brazil. A review. Mem Inst Oswaldo Cruz. 2005; 100:811-27.

16. Lainson R, Shaw JJ. Leishmaniasis in the New World. In: Collier L, Balows A, Sussman M, editors. Topley \& Wilson's Microbiology and Microbial Infections. Volume 5: Parasitology. 10 ${ }^{\text {th }}$ ed. London: Arnold; 2005. p. 313-349.

17. Lainson R, Shaw JJ, Lins ZC. Leishmaniasis in Brazil. IV. The fox, Cerdocyon thous (L.) as a reservoir of Leishmania donovani in Pará State, Brazil. Trans R Soc Trop Med Hyg. 1969;63:741-5.

18. Lainson R, Shaw JJ, Silveira FT, Braga RR. American visceral leishmaniasis: on the origin of Leishmania (Leishmania) chagasi. Trans R Soc Trop Med Hyg. 1987;81:517.

19. Lainson R, Dye C, Shaw JJ, MacDonald DW, Courtenay O, De Souza AAA, et al Amazonian visceral leishmaniasis: distribution of the vector Lutzomyia longipalpis (Lutz \& Neiva) in relation to the fox Cerdocyon thous (Linn.) and the efficiency of this reservoir host as a source of infection. Mem Inst Osvaldo Cruz. 1990;85:135-7.

20. Lima WG, Michalick MS, de Melo MN, Tafuri WL, Tafuri WL. Canine visceral leishmaniasis: a histopathological study of lymph nodes. Acta Trop. 2004;92:43-53.

21. Madeira MF, Schubach AO, Schubach TMP, Leal CA, Marzochi MCA. Identification of Leishmania (Leishmania) chagasi isolated from healthy skin of symptomatic and asymptomatic dogs seropositive for leishmaniasis in the municipality of Rio de Janeiro, Brazil. Braz J Infect Dis. 2004;8:440-4

22. McAllister MM; Parmley SF, Weiss LM, Welch VJ, McGuire AM. An immunohistochemical method for detecting bradyzoite antigen (BAG5) in Toxoplasma gondii-infected tissues cross-reacts with a Neospora caninum bradyzoite antigen. J. Parasitol. 1996;82:354-5

23. Molina R, Amela C, Nieto J, San-Andres M, Gonzalez F, Castillo JA, et al. Infectivity of dogs naturally infected with Leishmania infantum to colonized Phlebotomus perniciosus. Trans R Soc Trop Med Hyg. 1994;88:491-3.

24. Moreira MAB, Luvizotto MCR, Garcia JF, Corbett CEP, Laurenti MD. Comparison of parasitological, immunological and molecular methods for the diagnosis of leishmaniasis in dogs with different clinical signs. Vet. Parasitol., 2007;145:245-52.

25. Pereira EA, Chagas EJ, Jesus R, Carneiro LA, Jennings YL, Lima LV, et al A eliminação regular de cães soropositivos para leishmaniose visceral reduz a transmissão da enzootia canina em área endêmica. Rev Soc Bras Med Trop. 2006;39(Supl 1):115

26. Pitella JE, Meneguette C, Barbosa AJ, Bambirra EA. Histopathological and immunohistochemical study of the brain in the acute and chronic phases of experimental trypanosomiasis cruzi in dogs. Ann Trop Med Parasitol. 1990;84:615-21.

27. Salotra P, Sreenivas G, Beena KR, Mukherjee A, Ramesh V. Parasite detection in patients with post kala-azar dermal leishmaniasis in India: a comparison between molecular and immunological methods. J Clin Pathol. 2003;56:840-3.

28. Sanchez MA, Diaz NL, Zerpa O, Negron E, Convit J, Tapia FJ. Organ-specific immunity in canine visceral leishmaniasis: analysis of symptomatic and asymptomatic dogs naturally infected with Leishmania chagasi. Am J Trop Med Hyg. 2004;70: 618-24.

29. Saridomichelakis MN, Mylonakis ME, Leontides LS, Koutinas AF, Billinis C, Kontos VI. Evaluation of lymph node and bone marrow cytology in the diagnosis of canine leishmaniasis (Leishmania infantum) in symptomatic and asymptomatic dogs. Am J Trop Med Hyg. 2005;73:82-6

30. Secretaria Executiva de Saúde do Estado do Pará (Sespa). Leishmanioses visceral e tegumentar americana. In: Boletim Epidemiológico do Departamento de Controle de Endemias. Belém; 2004. p. 6-8. 


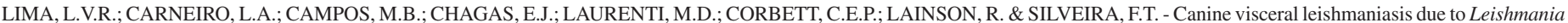
(L.) infantum chagasi in Amazonian Brazil: comparison of the parasite density from the skin, lymph node and visceral tissues between symptomatic and asymptomatic, seropositive dogs. Rev. Inst. Med. Trop. Sao Paulo, 52(5): 259-65, 2010

31. Silveira FT, Lainson R, Shaw JJ, Povoa MM. Leishmaniasis in Brazil. XVIII. Further evidence incriminating the fox Cerdocyon thous (L) as a reservoir of Amazonian visceral leshmaniasis. Trans R Soc Trop Med Hyg. 1982;76:830-2.

32. Silveira FT, Shaw JJ, Bichara CNC, Costa JML. Leishmaniose visceral americana In: Leão RNG, editor. Doenças infecciosas e parasitárias: enfoque amazônico. Belém: CEJUP; 1997. p. 631-44.

33. Silveira FT, Lainson R, Pereira EA, de Souza AAA, Campos MB, Chagas EJ, et al. A longitudinal study on the transmission dynamics of human Leishmania (Leishmania) infantum chagasi infection in Amazonian Brazil, with special reference to its prevalence and incidence. Parasitol Res. 2009;104:559-67.
34. Tafuri WL, Santos RL, Arantes RM, Gonçalves R, de Melo MN, Michalick MS, et al An alternative immunohistochemical method for detecting Leishmania amastigotes in paraffin-embedded canine tissues. J Immunol Methods. 2004;292:17-23.

Received: 13 May 2010

Accepted: 26 July 2010 